\title{
Burden of herpes zoster among Brazilian adults - a hospital-based study
}

\author{
Carga da herpes zoster em adultos brasileiros - \\ um estudo de base hospitalar
}

\author{
Ariane de Jesus Lopes de Abreu ${ }^{a}$, Amanda Venys ${ }^{\mathrm{b}} \bullet$, Wilson Jacob ${ }^{\mathrm{C}}$, Thiago da Silva ${ }^{\mathrm{C}}$, \\ Angela Henrique $^{b} \oplus$, Kusuma Gopalac $\bullet$, Eliana Nogueira Castro de Barros ${ }^{c} \oplus$
}

OBJECTIVE: To describe the clinical features of herpes zoster in adult patients treated at a large tertiary care hospital in Brazil over a 5-year period. METHODS: The medical records of suspected herpes zoster cases (based on ICD-10 codes) were identified for full review. Convenience sampling was used to select the medical records from a tertiary hospital in São Paulo. We collected data about co-existing medical conditions, medication use, herpes zoster-related clinical features and outcomes, and healthcare resource utilization. RESULTS: A total of 249 individuals whose first episode of herpes zoster occurred between 2010 and 2014 were included. The mean patient age was 55 years (range 18-96), and the majority were women (63.05\%) and aged $\geq 50$ years (63.86\%). Medical comorbidities were reported in 92.77\%, including diabetes (19.68\%) and HIV infection (7.63\%). Current/recent use of immunosuppressive agents was reported in $31.73 \%$. A total of $65.86 \%$ of the patients were hospitalized: 102 patients (40.96\%) were admitted for herpes zoster management, while 62 (24.90\%) were already receiving inpatient care. The mean hospital length of stay was 16.60 days. One-third (34.14\%) were managed as outpatients. Postherpetic neuralgia was reported as a complication in $18.07 \%$. CONCLUSIONS: This retrospective descriptive study found a high frequency of herpes zoster episodes in older adults with comorbidities who sought medical care at a tertiary hospital. These results also underscore the importance of understanding the epidemiology of this disease and developing control strategies for these at-risk populations in Brazil.

KEYWORDS: herpes zoster; neuralgia, postherpetic; epidemiology; aged.

OBJETIVO: Descrever as características clínicas do herpes zoster em pacientes adultos atendidos em um grande hospital terciário no Brasil por um período de cinco anos. METODOLOGIA: Os casos suspeitos de herpes zoster (com base nos códigos da CID-10) foram identificados para revisão completa dos prontuários. Foi realizada uma amostragem por conveniência para selecionar os prontuários de interesse em um hospital terciário em São Paulo. Foram coletadas informações de prontuários médicos sobre condições coexistentes, características clínicas e uso de medicamentos relacionados ao herpes zoster (como primeiro episódio ou episódio de herpes zoster recorrente) e uso de recursos de saúde. RESULTADOS: Entre 2010 e 2014, 249 indivíduos com um primeiro episódio de herpes zoster foram incluídos, com uma idade média de 55 anos (variando de 18 a 96 anos). A maioria era do sexo feminino (63,05\%) e com idade $\geq 50$ anos (63,86\%). Comorbidades médicas foram relatadas em 92,77\% dos pacientes, incluindo diabetes (19,68\%) e infecção por HIV (7,63\%); o uso atual / recente de agentes imunossupressores foi relatado em 31,73\%. Hospitalização foi relatada em 65,86\% dos casos; 102 pacientes (40,96\%) foram admitidos para o tratamento do episódio de herpes zoster e 62 pacientes $(24,90 \%)$ já estavam recebendo atendimento hospitalar. O tempo médio de permanência no hospital foi de 16,60 dias. Um terço $(34,14 \%)$ de todos os casos foi tratado ambulatorialmente. A neuralgia pós-herpética foi relatada como complicação em 18,07\% dos casos. CONCLUSÕES: Os resultados do presente estudo descritivo retrospectivo demonstram alta frequência de episódios de herpes zoster em idosos com comorbidades, buscando atendimento médico em um hospital terciário. Esses resultados também ressaltam a importância de entender a epidemiologia dessa doença e considerar as estratégias de controle nas populações de risco no Brasil. PALAVRAS-CHAVE: herpes zoster; neuralgia pós-herpética; epidemiologia; idoso.

anternational Vaccine Institute Seoul - Seoul, Republic of Korea.

bUniversidade de São Paulo - São Paulo (SP), Brazil.

'GSK- São Paulo (SP), Brazil.

Correspondence data

Ariane de Jesus Lopes de Abreu - SNU Research Park, 1 Gwanak-ro, Gwanak-gu - 08826 - Seoul, Republic of Korea. E-mail: arianeabreu.rj@gmail.com Received on: 01/24/2021. Accepted on: 06/05/2021.

How to cite this article: Abreu AJL; Venys A; Jacob W; Silva T; Henrique A; Gopala K; Barros ENC. Burden of herpes zoster among Brazilian adults a hospital-based study. Geriatr Gerontol Aging. 2021;15:e0210035. https://doi.org/10.53886/gga.e0210035

https://doi.org/10.53886/gga.e0210035 


\section{INTRODUCTION}

Herpes zoster $(\mathrm{HZ})$ is a painful and distressing condition caused by the reactivation of latent varicella-zoster virus in the cranial nerve or dorsal root ganglia. ${ }^{1}$ Viral reactivation initiates within the ganglia, with the virus migrating along the affected sensory nerve to the skin. Over $90.00 \%$ of all adults have been infected with varicella-zoster virus (usually in childhood) and are at risk of $\mathrm{HZ}$ in later life. Most cases of $\mathrm{HZ}$ present with systemic symptoms and a painful unilateral vesicular dermatomal rash that typically resolves within 2-4 weeks. However, pain may persist after the rash heals. Postherpetic neuralgia (PHN), defined as pain lasting $\geq 90$ days after rash onset, is the most frequently reported complication..$^{1,2}$

The global lifetime risk of $\mathrm{HZ}$ in the general population is approximately $10.00-30.00 \%$, with higher risk in females and a notably higher incidence in adults $\geq 50$ years of age, including a progressively greater incidence with increasing age. ${ }^{3-5}$ Individuals with impaired immunity and those with chronic medical conditions are also at higher risk of $\mathrm{HZ}$ and PHN. .,4,6,7 $^{2}$

The epidemiology of $\mathrm{HZ}$ in Brazil is not well understood. The most recent study, published 30 years ago, estimated an incidence of 5.62 cases per 1,000 person-years. ${ }^{3,8}$ More recent data indicate that the burden of $\mathrm{HZ}$ and associated economic costs may be substantial. ${ }^{9-11}$ The demographic shift in Brazil towards an aging population ${ }^{12}$ suggests that the healthcare costs of $\mathrm{HZ}$ and associated complications may be high. Understanding the disease's epidemiology and developing control strategies to reduce the burden of both $\mathrm{HZ}$ and PHN may provide significant public health benefits.

The purpose of this study was three-fold:

(i) to evaluate the clinical features of $\mathrm{HZ}$ and its complications in adults $\geq 18$ years who were treated at a large tertiary university hospital in Brazil;

(ii) to describe the disease burden in individuals with specific medical conditions/comorbidities;

(iii) to evaluate healthcare resource utilization (in terms of hospitalizations and outpatient cases) for these patients.

In addition, since most global epidemiologic data indicates a cumulative increase in incidence with increasing age, chiefly from 50 years of age onwards, we report on pertinent aspects in older adults. Although the definition of older adults can be fluid and often context specific, for the purposes of this manuscript, we consider older adults to be $\geq 50$ years of age. This aligns with the age-based eligibility for available vaccines against $\mathrm{HZ}^{13,14}$ and with the older adult age threshold used in policy groups, such as the International Council on Adult Immunization. ${ }^{15}$ Where practical, we also report data for older age strata, i.e., $\geq 60$ and $\geq 70$ years of age.

\section{METHODS}

\section{Study overview and population}

This retrospective observational study (GSK study identifier: 204498) was conducted at a single reference hospital in Brazil, the Hospital das Clínicas of the University of São Paulo Medical School. This tertiary care university hospital was selected because it is one of the largest hospitals in Brazil, with over 2,000 beds and 66,000 hospitalizations and 1.2 million outpatient medical visits each year. The local institutional review board approved the study, which was conducted following the International Conference on Harmonization Guidelines for Good Clinical Practices and the principles of the Declaration of Helsinki, as well as the regulations of the National Ethics and Research Committee (CONEP).

\section{Data sources and collection}

We retrospectively searched the hospital records of adults aged $\geq 18$ years between January 2010 and December 2014, using relevant ICD-10 codes for HZ (B02.0, B02.1, B02.2, B02.3, B02.7, B02.8, and B02.9) and free search terms (including 'herpes zoster') to generate a list of potentially eligible cases. All duplicate or potentially duplicate records were removed.

The medical records of eligible patients were accessed and reviewed by a physician, and data on demographics, patient medical history, clinical features of the $\mathrm{HZ}$ case, treatment, and clinical outcomes of eligible patients were collected. For the present study, $\mathrm{HZ}$ cases were classified into one of two categories: 'definite' cases, which included description of a rash and pain, with a clearly described dermatome or $\mathrm{HZ}$ complication; and 'probable' cases, which included a rash and pain but no explicitly described dermatome, or cases with an atypical rash in a clearly described dermatome but with no pain or complications. Cases with no clinical evidence of $\mathrm{HZ}$ or those with a diagnosis which ruled out $\mathrm{HZ}$ upon chart review were excluded.

Case identification and medical chart review were limited by the availability of records, which were often archived off-site. A convenience sampling approach was applied to identify suitable cases for inclusion, given the limited availability of records. The final sample included contactable patients (from whom informed consent was obtained) and uncontactable patients (due to death or three unsuccessful 
telephone calls) for whom a confidentiality agreement was signed by the investigator.

For these patients, the demographic data from each medical chart were entered into a standardized electronic case report form including: age, sex, date of diagnosis, medical specialty (e.g., dermatology, neurology), and medical history, which included pre-existing conditions and recent (within 30 days of the $\mathrm{HZ}$ episode) or current use of immunosuppressive medications. $\mathrm{HZ}$ disease-specific data included the date of symptom onset, clinical features (rash location, prodromal symptoms, and episode duration), complications, and the presence and duration of pain. For healthcare resource utilization related to the $\mathrm{HZ}$ episode, hospitalization and length of stay (LOS), number of outpatient cases, and prescribed medications were all recorded in the electronic case report form.

\section{Data analysis}

The data were tabulated overall and according to the following categories: definite and probable $\mathrm{HZ}$, first or recurrent $\mathrm{HZ}$ episode (defined as any new reported pain or rash after four consecutive weeks with no complaints of rash and/or pain from the first episode of HZ), age, comorbidity, and type of immunosuppressive therapy. Descriptive statistics were applied to all data. For continuous variables (e.g., age, LOS), the data were reported as mean with standard deviation (SD) and range, or minimum and maximum as appropriate. Discrete variables (e.g., number of patients) were reported as counts and percentages. All statistical analyses were performed in SAS version 9.2 (SAS Institute Inc., Cary, NC, USA).

\section{RESULTS}

\section{Study cohort}

Our search strategy identified a total of 624 eligible cases between 2010 and 2014 that were considered suitable for chart review and possible inclusion. Of these, 345 were excluded due to limited access to medical records or refusal to participate. Thus, a total of 259 patients with $\mathrm{HZ}$ were included (Figure 1). A first episode of $\mathrm{HZ}$ was reported in

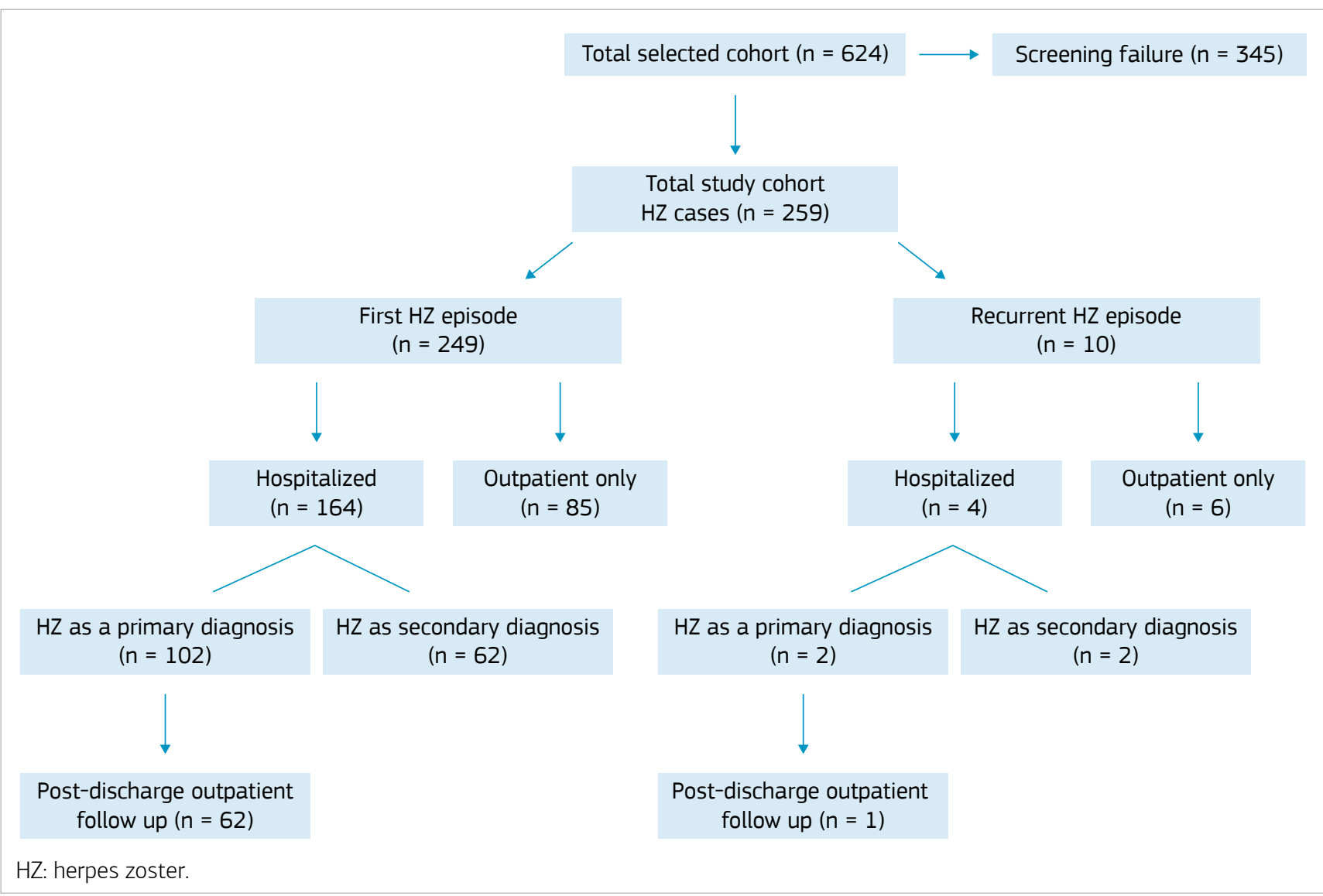

Figure 1. Total study cohort: $\mathrm{HZ}$ in adults $\geq 18$ years attending Hospital das Clinicas of the University of São Paulo Medical School (January 2010-December 2014). 


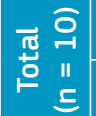

\begin{tabular}{ll|l|l|l|l|l|l|l|l|l|l|l|} 
& \\
\hline
\end{tabular}

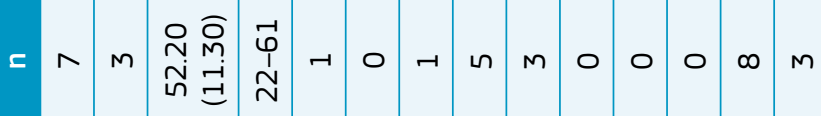

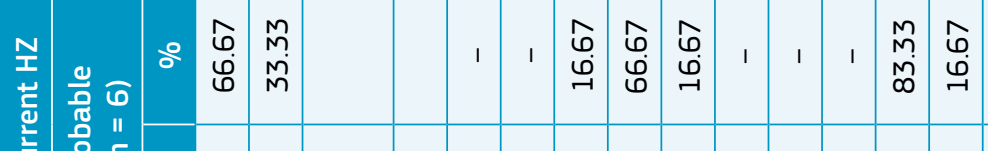
焉

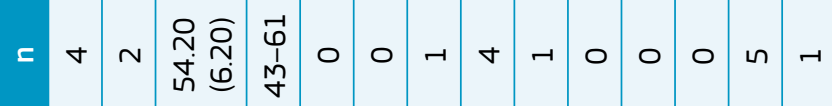

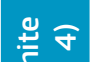

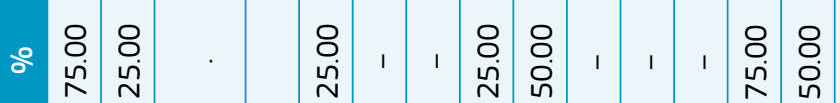

듬

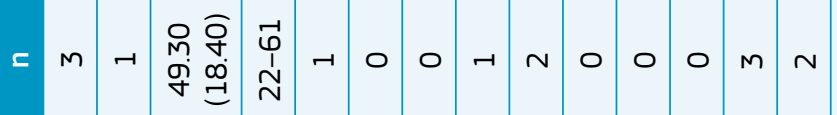

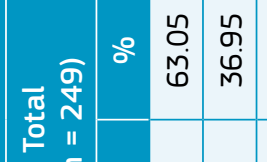

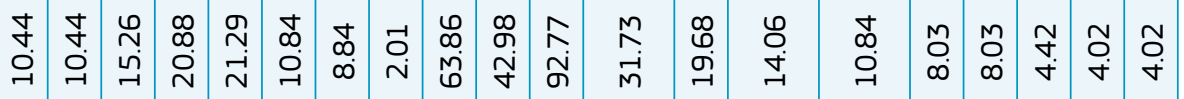

든

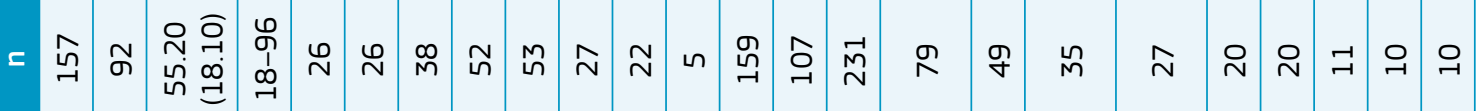

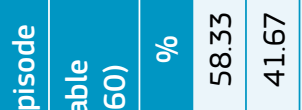

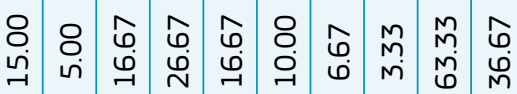

소 온 드

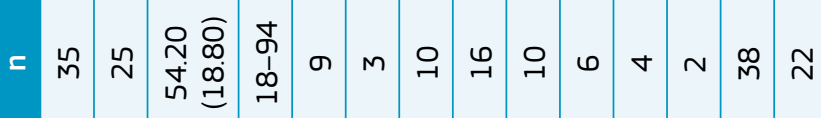

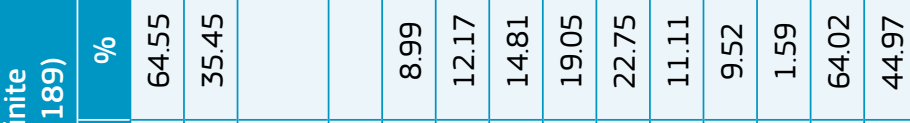

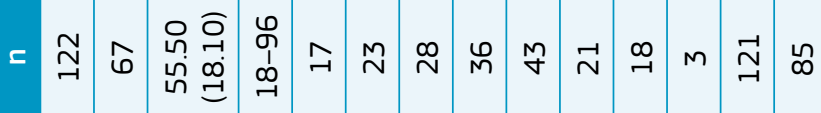

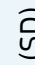

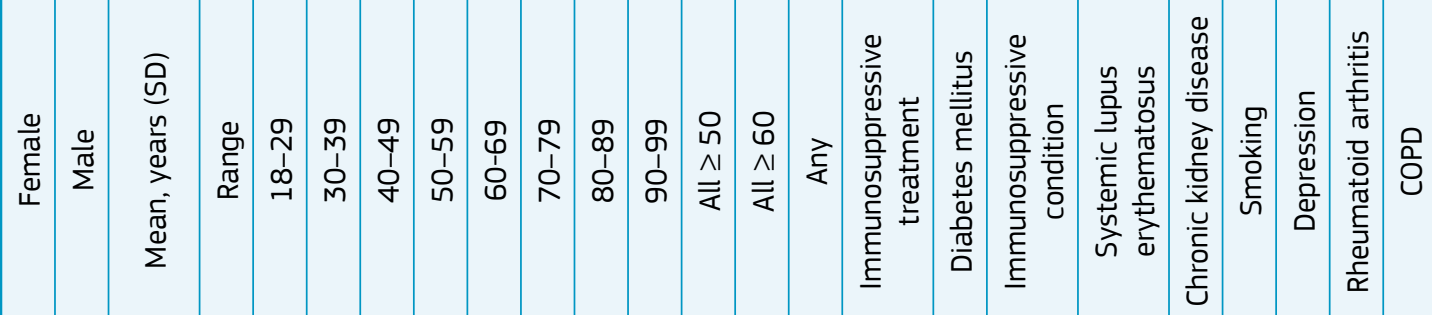

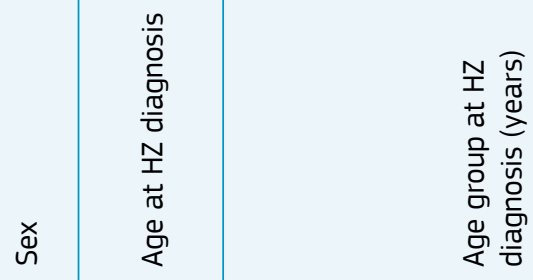

: 


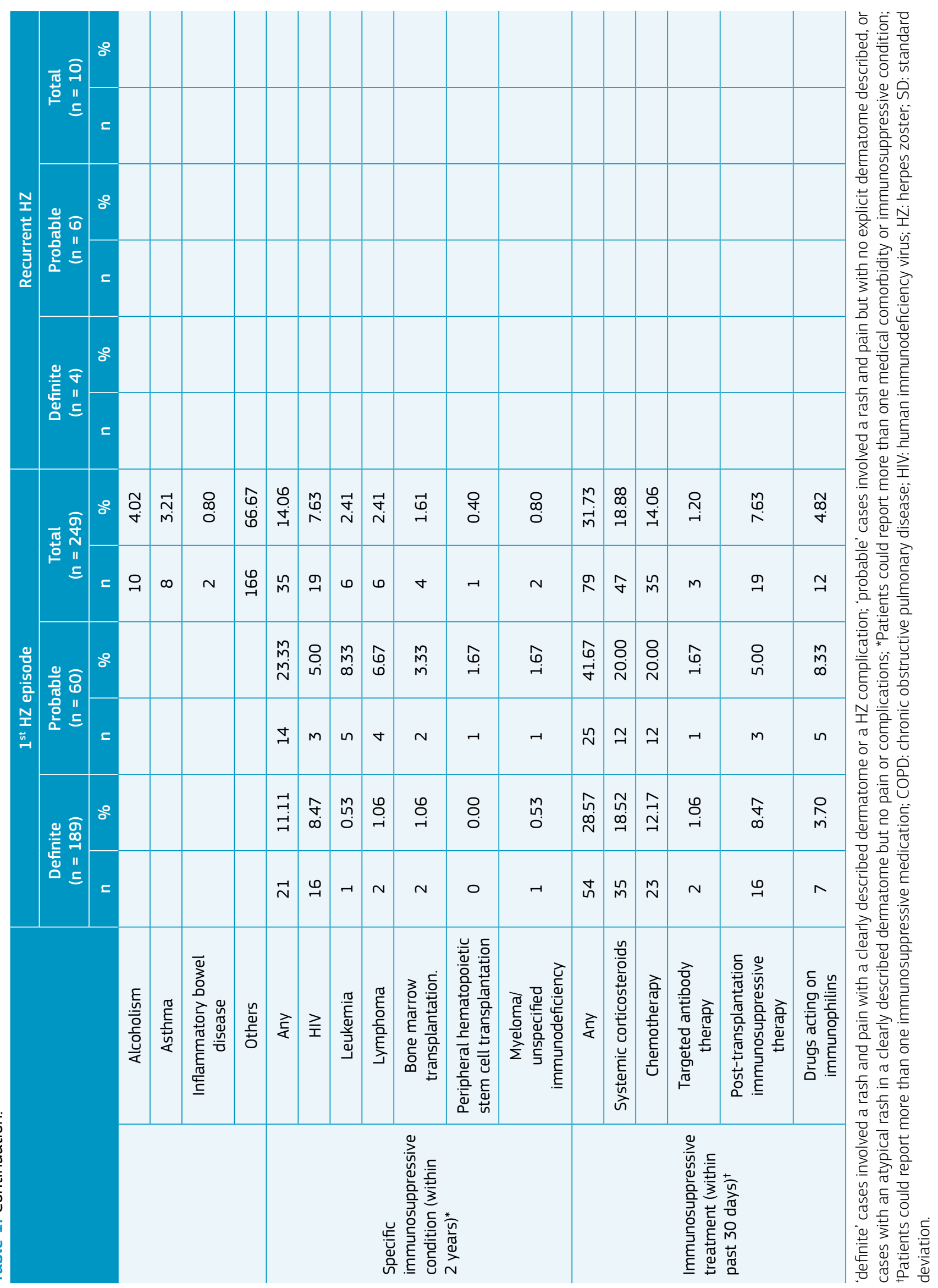


249 patients, of whom 189 were classified as 'definite' HZ cases and 60 as 'probable' (Table 1). The mean age at diagnosis of a first episode of $\mathrm{HZ}$ was 55 years (range 18-96); $63.05 \%$ of the patients were women. The majority (63.86\%) of the patients were aged $\geq 50$ years $(42.98 \% \geq 60$ years and $21.69 \% \geq 70$ years). Although there was no clear trend from year to year, more first episodes were reported in 2010 than the subsequent years (60 in 2010, 47 in 2011, 45 in 2012, 49 in 2013, and 48 in 2014). Recurrent HZ was identified in 10 patients ( 4 definite and 6 probable), whose mean age was 52 years (range $22-61) ; 70.00 \%$ were women. There was no clear trend regarding recurrent HZ. A single case occurred in 2010, 3 cases in 2013, and 2 in each of the other years.

Of the 249 patients with a first episode of HZ, 164 (65.86\%) were hospitalized (Table 2). These included 102 (40.96\%) admitted for $\mathrm{HZ}$ as the primary diagnosis and 62 (24.90\%) who were already receiving inpatient care for coexisting medical conditions (in whom $\mathrm{HZ}$ was coded as a secondary diagnosis). Four of the 10 (40.00\%) recurrent $\mathrm{HZ}$ patients were hospitalized. In our overall cohort, most of those hospitalized with $\mathrm{HZ}$ (either as a first or recurrent $\mathrm{HZ}$ episode) were $\geq 50$ years of age $(63.70 \%),(44.00 \%$ aged $\geq 60$ years and $22.60 \% \geq 70$ years of age). Almost two-thirds (64.10\%) of all patients aged $\geq 50$ years were either already hospitalized or were admitted for $\mathrm{HZ}$ management $(67.30 \%$ aged $\geq 60$ years and $70.40 \%$ aged $\geq 70$ years).

Of the 249 first-episode patients, 85 (34.14\%) were treated as outpatients, as were 6 out of 10 with recurrent HZ. The overall number of cases, including those hospitalized or managed on an outpatient basis in different age strata, is shown in Figure 2A.

\section{Clinical features}

The clinical characteristics of patients with $\mathrm{HZ}$ are shown in Table 1. Pre-existing medical conditions were reported in 231 of the 249 first-episode patients (92.77\%). The most common comorbidities were diabetes mellitus (19.68\%) and autoimmune diseases such as systemic lupus erythematosus (SLE) (10.84\%) and rheumatoid arthritis (4.02\%). Immunosuppressive conditions were present in 35 patients (14.06\%), including 19 individuals with HIV infection (7.63\%) and 12 with leukemia or lymphoma (4.82\%). A total of 79 patients (31.73\%) were receiving immunosuppressive agents, either currently or within the previous 30 days. Immunosuppressive agents included systemic corticosteroids (18.88\%), chemotherapy (14.06\%), and post-transplantation immunosuppressive therapy (7.63\%) (Table 1).

The patients were first seen by a broad range of specific medical specialists for the initial HZ diagnosis, including dermatologists (10.00\%) and infectious diseases units (7.30\%). Subsequent referral to manage special cases was common (119 patients) and mainly to dermatologists, neurologists, and infectious diseases units (Figure 2B).

Of the 259 patients with either a first or recurrent episode of HZ, 246 (95.00\%) experienced a rash, which generally occurred on the head or face (28.50\%), the back $(26.40 \%)$, or the chest (23.60\%) (Figure 2C). Symptoms were reported by 204 of the 249 first-episode patients (81.93\%). Pain, the most common symptom, was reported in 175 patients $(85.78 \%)$ (Table 2). Other frequently reported symptoms included itching (22.06\%) and fever (20.10\%). Symptoms were more common in 'definite' first-episode cases than 'probable' cases. In recurrent $\mathrm{HZ}$, symptoms other than pain were seldom reported (Table 2).

The majority of patients $(64.00 \%)$ with either a first or a recurrent episode received standard medication (therapeutic and/or symptom management). Intravenous and oral antivirals were the most frequently reported therapies, while gabapentin was the most frequently administered analgesic (Figure 2D).

Complications were reported in 121 (48.59\%) of 249 first-episode patients (Table 2). The most frequently reported complications were neurological $(56.20 \%$ of all complications), which affected 68 patients (27.31\% of the sample). PHN was reported in 45 patients ( $18.07 \%$ of the sample), the vast majority $(84.44 \%)$ of whom were aged $\geq 50$ years (62.20\% were aged $\geq 60$ years). Moreover, $\mathrm{PHN}$ was a reported complication in $26.20 \%$ of all patients $\geq 60$ years of age. After adjusting for case numbers, $\mathrm{PHN}$ was more prevalent in patients aged $\geq 50$ years than in younger adults $(23.90 \%$ vs. $7.78 \%$ ). Persistent pain not categorized as PHN was reported in $6.83 \%$ of the patients, while 11 patients developed meningoencephalitis. Cutaneous complications were reported in $23.69 \%$ of the first-episode group, most commonly from bacterial superinfection. Ophthalmic complications were relatively infrequent and visceral complications were rare. The vast majority of complications were reported among 'definite' cases (Table 2).

\section{Healthcare resource utilization}

The mean hospital LOS for first-episode cases of $\mathrm{HZ}$ ( $\mathrm{n}=164$ ) was 16.60 days (range 2-80 days), although LOS varied depending on the case type: 14.80 days (range $2-80$ days) for 'definite' cases and 22.40 days (range 2-75 days) for 'probable' cases. The mean LOS of patients hospitalized for a recurrent $\mathrm{HZ}$ episode ( $\mathrm{n}=4$ ) was 22.30 days (range 3-67 days). A total of 62 patients were hospitalized for a first episode of $\mathrm{HZ}(37.80 \%)$, and 1 individual with recurrent $\mathrm{HZ}$ was 
Table 2. Clinical features and complications.

\begin{tabular}{|c|c|c|c|c|c|c|c|c|c|c|c|c|c|}
\hline & \multicolumn{6}{|c|}{ 1st episode of $\mathrm{HZ}$} & \multicolumn{6}{|c|}{ Recurrent HZ } \\
\hline & & \multicolumn{2}{|c|}{$\begin{array}{l}\text { Definite } \\
(n=189)\end{array}$} & \multicolumn{2}{|c|}{$\begin{array}{c}\text { Probable } \\
(\mathrm{n}=60)\end{array}$} & \multicolumn{2}{|c|}{$\begin{array}{c}\text { Total } \\
(n=249)\end{array}$} & \multicolumn{2}{|c|}{$\begin{array}{l}\text { Definite } \\
(n=4)\end{array}$} & \multicolumn{2}{|c|}{$\begin{array}{l}\text { Probable } \\
(n=6)\end{array}$} & \multicolumn{2}{|c|}{$\begin{array}{c}\text { Total } \\
(n=10)\end{array}$} \\
\hline & & $\mathrm{n}$ & $\%$ & \begin{tabular}{l|l}
$n$ & \\
\end{tabular} & $\%$ & $n$ & $\%$ & $n$ & $\%$ & $n$ & $\%$ & $\mathrm{n}$ & $\%$ \\
\hline \multirow{3}{*}{$\begin{array}{l}\text { Any symptoms } \\
\text { during the } \mathrm{HZ} \\
\text { episode* }\end{array}$} & Yes & 182 & 96.30 & 22 & 37.67 & 204 & 81.93 & 4 & 100.00 & 1 & 16.67 & 5 & 50.00 \\
\hline & No & 1 & 0.53 & 11 & 18.33 & 12 & 4.82 & 0 & - & 0 & - & 0 & - \\
\hline & Missing data & 6 & 3.17 & 27 & 45.00 & 33 & 13.25 & 0 & - & 5 & & 5 & 50.00 \\
\hline \multirow{9}{*}{ Specific symptom } & Pain & 171 & 90.48 & 4 & 6.67 & 175 & 70.28 & 4 & 100.00 & 0 & - & 4 & 40.00 \\
\hline & Fever & 37 & 19.58 & 4 & 6.67 & 41 & 16.47 & 0 & - & 0 & - & 0 & - \\
\hline & Malaise & 9 & 4.76 & 3 & 5.00 & 12 & 4.82 & 1 & 25.00 & 0 & - & 1 & 10.00 \\
\hline & Itching & 33 & 17.46 & 12 & 20.0 & 45 & 18.07 & 0 & - & 1 & 100.00 & 1 & 10.00 \\
\hline & Numbness & 6 & 3.17 & 3 & 5.00 & 9 & 3.61 & 0 & - & 0 & - & 0 & - \\
\hline & Tingling & 6 & 3.17 & 0 & - & 6 & 2.41 & 0 & - & 0 & - & 0 & - \\
\hline & Chills & 4 & 2.12 & 0 & - & 4 & 1.61 & 0 & - & 0 & - & 0 & - \\
\hline & Myalgia & 6 & 3.17 & 0 & - & 6 & 2.41 & 0 & - & 0 & - & 0 & - \\
\hline & Other & 22 & 11.64 & 3 & 5.00 & 25 & 10.04 & 1 & 25.00 & 0 & - & 1 & 20.00 \\
\hline \multirow{3}{*}{$\begin{array}{l}\text { Any } \\
\text { complications } \\
\text { during the HZ } \\
\text { episode* }\end{array}$} & Yes & 117 & 61.90 & 4 & 6.67 & 121 & 48.59 & 1 & 25.00 & 0 & - & 1 & 10.00 \\
\hline & No & 25 & 13.23 & 20 & 33.33 & 45 & 18.07 & 2 & 50.00 & 1 & 16.67 & 3 & 30.00 \\
\hline & Missing data & 47 & 24.87 & 36 & 60.00 & 83 & 33.33 & 1 & 25.00 & 5 & 83.33 & 6 & 60.00 \\
\hline \multirow{4}{*}{ Neurological } & Any & 66 & 34.92 & 2 & 3.33 & 68 & 27.31 & 1 & 25.00 & 0 & - & 1 & 10.00 \\
\hline & $\mathrm{PHN}$ & 44 & 23.28 & 1 & 1.67 & 45 & 18.07 & 1 & 25.00 & 0 & - & 1 & 10.00 \\
\hline & $\begin{array}{l}\text { Persistent } \mathrm{HZ} \\
\text { related pain }\end{array}$ & 17 & 8.99 & 0 & - & 17 & 6.83 & 0 & - & 0 & - & 0 & - \\
\hline & Meningoencephalitis & 10 & 5.29 & 1 & 1.67 & 11 & 4.42 & 0 & - & 0 & - & 0 & - \\
\hline \multirow{3}{*}{ Cutaneous } & Any & 57 & 30.16 & 2 & 3.33 & 59 & 23.69 & 0 & - & 0 & - & 0 & - \\
\hline & $\begin{array}{c}\text { Bacterial } \\
\text { superinfection }\end{array}$ & 52 & 27.51 & 2 & 3.33 & 54 & 21.69 & 0 & - & 0 & - & 0 & - \\
\hline & Scarring & 3 & 1.59 & 0 & - & 3 & 1.20 & 0 & - & 0 & - & 0 & - \\
\hline \multirow{3}{*}{ Ophthalmic } & Any & 20 & 10.58 & 0 & - & 20 & 8.03 & 0 & - & 0 & - & 0 & - \\
\hline & Keratitis & 8 & 4.23 & 0 & - & 8 & 3.21 & 0 & - & 0 & - & 0 & - \\
\hline & Visual Impairment & 4 & 2.12 & 0 & - & 4 & 1.61 & 0 & - & 0 & - & 0 & - \\
\hline Visceral & Any & 1 & 0.53 & 0 & - & 1 & 0.40 & 0 & - & 0 & - & 0 & - \\
\hline \multicolumn{14}{|c|}{ Healthcare resource use } \\
\hline \multirow{3}{*}{ Hospitalizations } & Overall & 125 & 66.14 & 39 & 65.00 & 164 & 65.86 & 2 & 50.00 & 2 & 33.33 & 4 & 40.00 \\
\hline & $\begin{array}{c}\mathrm{HZ} \text { as the primary } \\
\text { diagnosis }\end{array}$ & 95 & 50.26 & 7 & 11.67 & 102 & 40.96 & 2 & 50.00 & 0 & - & 2 & 20.00 \\
\hline & $\begin{array}{l}\text { HZ as the } \\
\text { secondary } \\
\text { diagnosis }\end{array}$ & 30 & 15.87 & 32 & 53.33 & 62 & 24.90 & 0 & - & 2 & 33.33 & 2 & 20.00 \\
\hline \multirow{2}{*}{$\begin{array}{l}\text { Duration of } \\
\text { hospitalization }\end{array}$} & Mean, days & 14.80 & & 22.40 & & 16.60 & & 4.50 & & 40.00 & & 22.30 & \\
\hline & Range & $2-80$ & & $2-75$ & & $2-80$ & & $3-7$ & & $13-67$ & & $3-67$ & \\
\hline $\begin{array}{l}\text { Post-discharge } \\
\text { follow-up in } \\
\text { outpatient care }{ }^{\dagger}\end{array}$ & Yes & 56 & 44.80 & 6 & 15.38 & 62 & 37.80 & 1 & 50.00 & - & - & 1 & 25.00 \\
\hline $\begin{array}{l}\text { Outpatient } \\
\text { care only }\end{array}$ & & & & & & 85 & 34.15 & & & & & 6 & 60.00 \\
\hline
\end{tabular}

*Patients could report more than one symptom or complication; ${ }^{\dagger}$ Percentages calculated based on the number of hospitalized patients as the denominator; HZ: herpes zoster; PHN: postherpetic neuralgia; SD: standard deviation. 
A

A

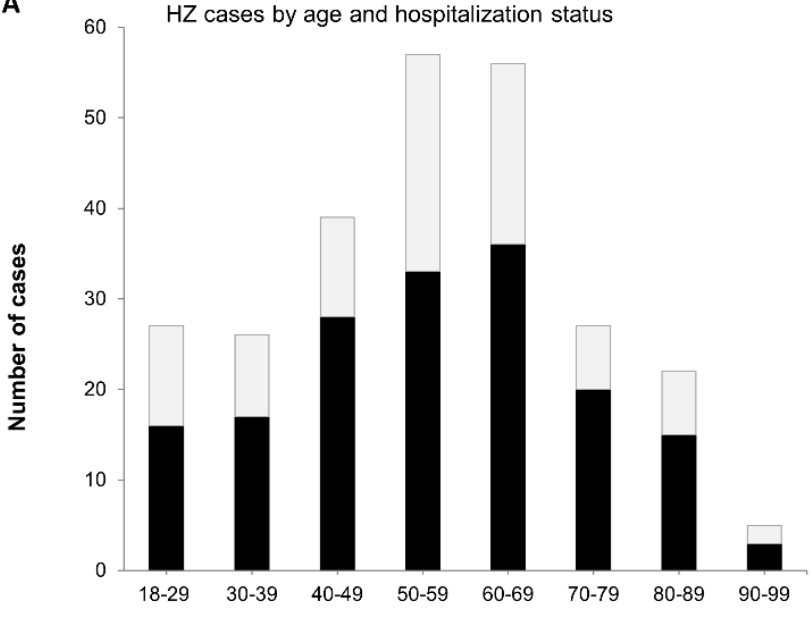

$\square$ Outpatient $H Z$ cases $(n=91) \quad \square$ Hospitalized $H Z$ cases $(n=168)$

C

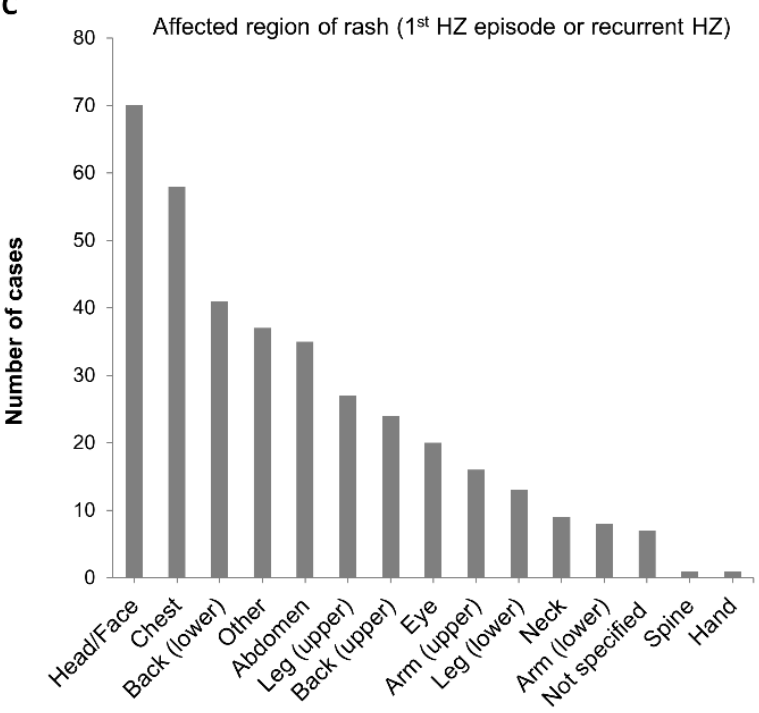

B

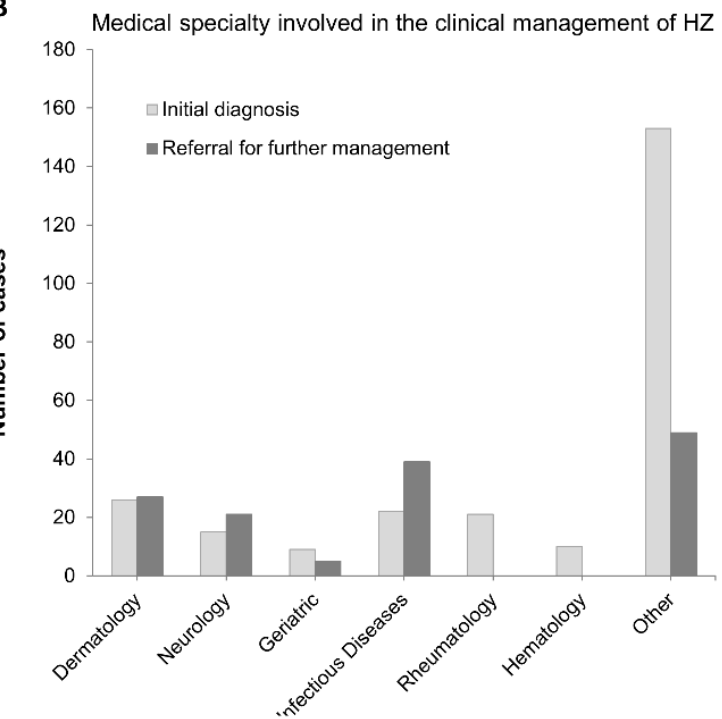

D

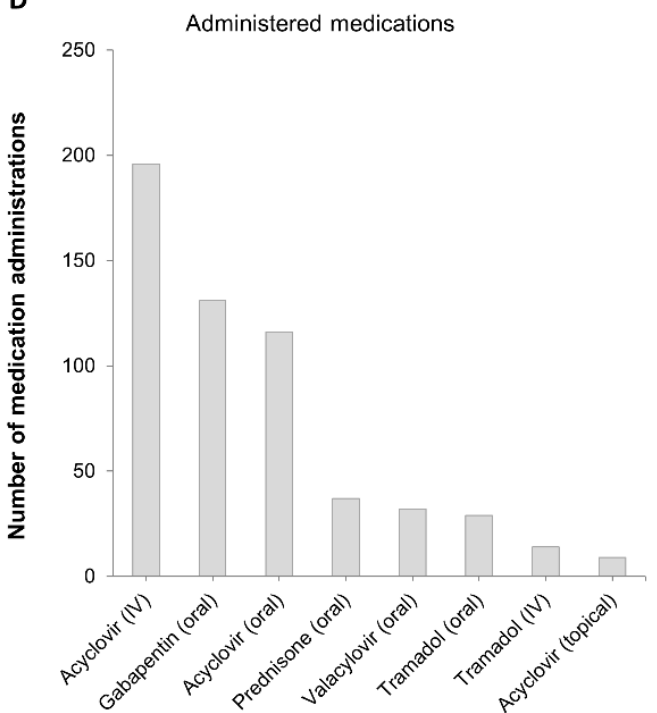

HZ: herpes zoster.

Figure 2. Clinical characteristic of study cohort.

followed up on an outpatient basis after discharge (Table 2). A total of 85 of 249 first-episode patients (34.14\%) and 6 out of 10 recurrent patients were managed solely on an outpatient basis.

\section{Disease outcomes in older adults}

The majority of our cohort was aged $\geq 50$ years $(63.85 \%$ of first-episode cases). Although not part of our pre-specified analyses, post hoc comparisons of older vs. younger patients showed that a higher proportion of younger patients had a predisposing immunosuppressive condition (25.60 vs $7.50 \%$ ); including SLE (23.33 vs 3.77\%) and HIV (15.56 vs 3.14\%) (Table 3). Current or recent immunosuppressive treatment was more common in younger patients (41.11 vs $26.42 \%$ ). In contrast, diabetes mellitus was more common in older patients (25.79 vs $8.89 \%)$.

Although the majority of patients hospitalized for a $\mathrm{HZ}$ episode were older adults (63.69\%), the relative proportions of hospitalized younger and older adults were broadly comparable, with approximately two-thirds of each group receiving 
Table 3. Selected outcomes in older and younger patients.

\begin{tabular}{|c|c|c|c|c|}
\hline & \multicolumn{2}{|c|}{$\begin{array}{l}\geq 50 \text { years } \\
(n=159)^{*}\end{array}$} & \multicolumn{2}{|c|}{$\begin{array}{c}<50 \text { years } \\
(n=90)^{*}\end{array}$} \\
\hline & $n$ & $\%$ & $n$ & $\%$ \\
\hline Any comorbidity & 150 & 94.34 & 81 & 90.00 \\
\hline $\begin{array}{l}\text { Systemic lupus } \\
\text { erythematosus }\end{array}$ & 6 & 3.77 & 21 & 23.33 \\
\hline HIV & 5 & 3.14 & 14 & 15.56 \\
\hline Diabetes mellitus & 41 & 25.79 & 8 & 8.89 \\
\hline $\begin{array}{l}\text { Immunosuppressive } \\
\text { treatment }\end{array}$ & 42 & 26.42 & 37 & 41.11 \\
\hline Hospitalized $†$ & 107 & 64.07 & 61 & 66.30 \\
\hline Outpatient† & 60 & 35.93 & 31 & 33.70 \\
\hline $\begin{array}{l}\text { PHN as a } \\
\text { complication }\end{array}$ & 38 & 23.90 & 7 & 7.78 \\
\hline
\end{tabular}

${ }^{*} \mathrm{n}$ relates to number of first $\mathrm{HZ}$ episodes; ${ }^{\dagger} \mathrm{n}$ and percentages relate to patients with first $\mathrm{HZ}$ episodes or recurrent HZ: HIV: human immunodeficiency virus; $\mathrm{HZ}$ : herpes zoster; $\mathrm{PHN}$ : postherpetic neuralgia.

inpatient care (the other patients in each age category were treated solely on an outpatient basis).

There were no major differences in the pattern or prevalence of symptoms in younger and older patients, and the prevalence of most complications was either broadly comparable or could not be compared due to limited numbers. The one exception was PHN: $84.44 \%$ of patients who developed this complication were aged $\geq 50$ years and, as previously mentioned, $\mathrm{PHN}$ was more frequent in older patients than younger patients $(23.90$ vs. $7.78 \%$ ) (Table 3$)$.

\section{DISCUSSION}

This retrospective descriptive study evaluated the clinical characteristics of $\mathrm{HZ}$ in selected patients treated at a large tertiary care hospital in São Paulo between 2010 and 2014. Most of the patients in our cohort had medical comorbidities (e.g., diabetes mellitus), and many were immunocompromised (e.g., HIV infection) and/or were on immunosuppressants. We found that the prevalence of certain immunocompromising conditions (e.g., SLE and HIV) and immunosuppressive therapy was higher in younger patients, which was consistent with this recognizable risk factor in this age group, whereas ageing itself (i.e., the natural age-related decline in immunity) was more relevant in older adults., ${ }^{3,411,16}$ Over $60.00 \%$ of the patients were aged $\geq 50$ years, with $42.98 \% \geq 60$ years of age; the majority (70.00\%) were women. These demographic characteristics are similar to previous reports from
Brazil ${ }^{9,10}$ and elsewhere. ${ }^{3,4,11,16}$ Supplemental Figure 1 presents a plain-language summary of the context, outcomes, and relevance of this study for healthcare providers.

Clinically, most patients in our cohort presented with a rash (predominantly involving the cervical and thoracic regions) accompanied by pain. Central nervous system complications e.g., ocular involvement or meningoencephalitis, were relatively uncommon. One of the most common complications in our cohort was $\mathrm{PHN}$, which occurred in $18.07 \%$ of patients with a first episode of HZ. Most patients who developed PHN were $\geq 50$ years of age, and PHN was reported in 23.90\% of patients aged $\geq 50$ years. This relatively high prevalence is consistent with the results of studies conducted in Brazil and abroad. ${ }^{2,3}$ For example, a prospective study by Antoniolli et al. with a similar cohort (adults aged $\geq 18$ years) found a $22.10 \%$ prevalence of $\mathrm{PHN}$ in $\mathrm{HZ}$ patients. ${ }^{10}$ In contrast, a prospective study by Toniolo-Neto et al. of patients recruited from an emergency room in São Paulo, which included only adults $\geq 50$ years of age, reported an even higher PHN rate (49.30\%). ${ }^{9}$ Although neither of these studies assessed the relationship between $\mathrm{PHN}$ and age, the fact that $\mathrm{PHN}$ was more frequent in patients aged $\geq 50$ years than in younger patients is consistent with other data indicating a greater risk with increasing age. ${ }^{2,7}$

In our retrospective cohort study from 2010 to 2014, 164 of 249 (65.86\%) first-episode patients were hospitalized (the majority being $\geq 50$ years of age); the others were managed solely on an outpatient basis. $\mathrm{HZ}$ was the primary diagnosis in the majority of hospitalized patients (62.20\%), while the remaining $38.10 \%$ were already in hospital for other reasons. The majority of hospitalized patients were older adults $\geq 50$ years (63.69\%), which reflects the greater overall number of older patients in the sample. The relative proportions of younger and older hospitalized patients were broadly comparable and, although not formally analyzed, there was no evidence of an increased risk of hospitalization with increasing age.

Antoniolli et al. reported a higher rate of $\mathrm{HZ}$ in patients aged $\geq 18$ years who were already hospitalized for other reasons $(74.40 \%)$. A total of $22.30 \%$ were admitted to the emergency room with $\mathrm{HZ}$ as the primary diagnosis and relatively few (3.20\%) were managed solely on an outpatient basis. ${ }^{10}$ Their mean LOS for hospitalized patients (6.65 days, range $1-87)^{10}$ was shorter than ours ( 14.80 and 22.40 days for 'definite' and 'probable' HZ cases, respectively). Toniolo-Neto et al. reported that among patients aged $\geq 50$ years who were treated in the emergency room, $8.90 \%$ were hospitalized due to $\mathrm{HZ}$, and the duration of hospitalization was shorter (mean LOS 5.80 days) than in our cohort. ${ }^{9}$ The difference between the present study and these other Brazilian studies may reflect 
differences in methodology, i.e., study design, inclusion and exclusion criteria, study setting (e.g., emergency room, tertiary care, etc.), and study period (e.g., Toniolo-Neto et al. was conducted between 2008 and 2009 and Antoniolli et al. was conducted between 2010 and 2017). ${ }^{9,10}$ Neither of these Brazilian studies evaluated differences in disease patterns or outcomes between older and younger patients or reported details in older age strata ( $\geq 60$ or $\geq 70$ ). Indeed, comparative Latin American data are scarce regarding age-related differences in HZ. For example, although a relatively small study from Costa Rica described $\mathrm{HZ}$ characteristics in 50 patients (all older adults $>50$ years treated in geriatric primary care), the study demographics preclude age-related comparisons. ${ }^{16}$ Thus, we believe that our data, although limited, can help provide a greater understanding of $\mathrm{HZ}$ in this region's older adult population.

In the present study, patients with $\mathrm{HZ}$ were managed by various specialists both at initial diagnosis and subsequent referral for further inpatient or outpatient care (dermatologists, neurologists and infectious diseases experts), which may reflect the frequency of comorbidities among $\mathrm{HZ}$ patients. For primary treatment, intravenous acyclovir was the most frequent antiviral agent, although acyclovir was more commonly prescribed than valacyclovir for oral therapy. The relatively minor differences in treatment decisions may have been influenced by the setting (inpatient vs outpatient) and physician preference, as well as by specific clinical features. However, these treatment patterns are broadly similar to those of previous Brazilian studies. ${ }^{9}, 10$

Our findings should be interpreted in view of certain limitations related to the retrospective design and the use of search strategies to identify potential cases, including a subsequent chart review to collect clinical data from a single tertiary care hospital. Although we included 259 patients who were identified and selected through convenience sampling, this number represents only a portion of all individuals with $\mathrm{HZ}$ who were treated at the hospital during this period. Additional cases could not be evaluated due to limited data availability (outpatient care records), as well as problems obtaining informed consent. In addition, due to logistical reasons, other hospital units or centers (including the regional cancer institute) were not included in our search procedures. Consequently, our cohort underestimates the total number of treated patients between 2010 and 2014. Furthermore, the available data for our patients were often incomplete. For example, prior $\mathrm{HZ}$ vaccinations were not recorded, and so we cannot comment on the prevalence of $\mathrm{HZ}$ in previously vaccinated patients or on evidence of vaccine failure. In addition, findings from a single hospital may not necessarily reflect the conditions of the general Brazilian population.
Despite these limitations, our data can contribute to a greater understanding of the characteristics and the clinical management of $\mathrm{HZ}$ in Brazil. Our results support the view that $\mathrm{HZ}$ may represent a significant disease burden and can impact patient quality of life due to the high occurrence of complications, mainly among those who develop long-term pain, such as PHN. ${ }^{9}, 10$ Similar observations have been made in other studies from Latin America and elsewhere. . $^{2-4,711}$ Although the present study could not estimate the medical costs of $\mathrm{HZ}$ due to data limitations, other Latin American studies (including patients from Brazil) have found that direct and indirect medical costs of $\mathrm{HZ}$ are high, being even higher in patients with complications such as PHN. ${ }^{11}$

Considering the importance of $\mathrm{HZ}$, clear preventive measures to reduce the disease burden would be valuable, especially when combined with initiatives to promote better understanding of disease management among healthcare professionals. At present, there are effective vaccines to prevent $\mathrm{HZ}$ episodes or recurrent $\mathrm{HZ}$ in adults aged $\geq 50$ years, including a live attenuated herpes zoster vaccine (Zostavax, Merck Sharp \& Dohme) and, more recently, a novel subunit herpes zoster vaccine (Shingrix, GSK). ${ }^{13,14}$ The latter, a non-live vaccine, may help immunocompromised patients for whom live-attenuated vaccines are contraindicated. ${ }^{14,17}$ These vaccines could reduce the clinical and economic burden of $\mathrm{HZ}$ in Brazil, particularly in older adults and immunocompromised patients who experience complications.

\section{CONCLUSIONS}

The results of this retrospective descriptive study show a high proportion of $\mathrm{HZ}$ in older adults ( $\geq 50$ years of age) and immunocompromised patients treated at a large tertiary university hospital in Brazil and highlight the potential value of appropriate strategies, such as vaccination, in these at-risk populations.

\section{CONFLICTS OF INTEREST}

E.N.C.E. de Barros was employee of the GSK group of companies while this study was being conducted. K. Gopala is currently employed by the GSK group of companies. A. Abreu was employed by Shift Gestão de Serviços and reports being an outsourced employee for the GSK group of companies while this study was being conducted. W. Jacob-Filho, A. L. Venys, T. J. A. Silva and E. A. Henrique received grants from the GSK group of companies for participating in this study. The authors declare no other financial and non-financial relationships and activities. 


\section{FUNDING}

GlaxoSmithKline Biologicals SA funded this study and was involved in all stages of its development, including data analysis (GSK study identifier: 204498). GlaxoSmithKline Biologicals SA also covered all costs associated with the development and publication of this manuscript.

\section{ACKNOWLEDGEMENTS}

The authors would like to thank all the study staff, from GSK and research center from Hospital das Clínicas, who were essential and committed during the study. The authors wish to thank Susana Soares (GSK) for her role as local delivery lead for this study and her support in operational aspects and study design, and also the following for supporting operational aspects: Julia Andrade (GSK) and Patrícia Kurata (Pharmaceutical Product Development - PPD). From the research center staff, authors would like to thank Dr. Arlety Casale, who had a valuable participation in all phases of the study from Hospital das Clínicas, for her role as study coordinator. The authors are also grateful to Otavio Cintra (GSK) and Rodrigo DeAntonio (formerly of GSK) for their valuable inputs in study design and/or study execution. The authors would also like to thank Business \&
Decision Life Sciences platform for editorial assistance and publication coordination, on behalf of GSK. Pierre-Paul Prevot and Ingrid Leal coordinated manuscript development and editorial support. The authors also thank Iain O'Neill (freelance on behalf of GSK) for providing medical writing support.

\section{TRADEMARKS}

Shingrix is a trademark owned by or licensed to the GSK group of companies. Zostavax is a trademark of Merck Sharp \& Dohme

\section{AUTHOR CONTRIBUTIONS}

AJLA: conceptualization, project administration, supervision, validation, analysis and writing - original draft, writing review \& editing. AV: project administration and writing - review \& editing. WJ: supervision and writing - review \& editing. TS: project administration and writing - review \& editing. AH: project administration, writing - review \& editing. KG: methodology, formal analysis, writing - review \& editing. ENCB: conceptualization, methodology, supervision, analysis and writing - review \& editing.

\section{REFERENCES}

1. Cohen Jl. Clinical practice: Herpes zoster. N EngI J Med. 2013;369(3):25563. https://doi.org/10.1056/nejmcp1302674

2. Kawai K, Rampakakis E, Tsai TF, Cheong HJ, Dhitavat J, Covarrubias $\mathrm{AO}$, et al. Predictors of postherpetic neuralgia in patients with herpes zoster: a pooled analysis of prospective cohort studies from North and Latin America and Asia. Int J Infect Dis. 2015;34:126-31. https://doi.org/10.1016/j.ijid.2015.03.022

3. Kawai K, Gebremeskel BG, Acosta CJ. Systematic review of incidence and complications of herpes zoster: towards a global perspective. BMJ Open. 2014;4(6):e004833. https://doi.org/10.1136/bmjopen2014-004833

4. Kawai K, Yawn BP. Risk Factors for Herpes Zoster: A Systematic Review and Meta-analysis. Mayo Clin Proc. 2017;92(12):1806-21. https://doi.org/10.1016/j.mayocp.2017.10.009

5. Cohen KR, Salbu RL, Frank J, Israel I. Presentation and management of herpes zoster (shingles) in the geriatric population. P T. 2013;38(4):217-27. PMID: 23785227.

6. Forbes HJ, Bhaskaran K, Thomas SL, Smeeth L, Clayton T, Langan SM. Quantification of risk factors for herpes zoster: population based casecontrol study. BMJ. 2014;348:g2911. https://doi.org/10.1136/bmj.g2911

7. Forbes HJ, Bhaskaran K, Thomas SL, Smeeth L, Clayton T, Mansfield $\mathrm{K}$, et al. Quantification of risk factors for postherpetic neuralgia in herpes zoster patients: A cohort study. Neurology. 2016;87(1):94102. https://doi.org/10.1212/wnl.0000000000002808

8. Castro LGM, Chen S. Zoster: mais frequentes entre jovens que entre idosos/ Zoster: is more frequent among youngsters than aged. An Bras Dermatol. 1990;65(3):129-33.

9. Toniolo-Neto J, Psaradellis E, Karellis A, Rampakakis E, Rockett TY, Sampalis JS, et al. Measuring herpes zoster disease burden in Sao Paulo, Brazil: a clinico-epidemiological single-center study. Clinics (Sao Paulo). 2018;73:e243. https://doi.org/10.6061/clinics/2018/e243
10. Antoniolli L, Rodrigues C, Borges R, Goldani LZ. Epidemiology and clinical characteristics of herpes zoster in a tertiary care hospital in Brazil. Braz J Infect Dis. 2019;23(2)143-5. https://doi.org/10.1016/j. bjid.2018.03.001

11. Rampakakis E, Pollock C, Vujacich C, Toniolo Neto J, Ortiz Covarrubias A, Monsanto H, et al. Economic Burden of Herpes Zoster ("culebrilla") in Latin America. Int J Infect Dis. 2017;58:22-6. https://doi.org/10.1016/j. ijid.2017.02.021

12. Gragnolati M, Jorgensen O, Rocha R. Fruttero A. Growing Old in an Older Brazil: Implications of Population Ageing on Growth, Poverty, Public Finance, and Service Delivery. Washington (DC): World Bank, 2011.

13. Keating GM. Shingles (Herpes Zoster) Vaccine (Zostavax ((R))) A Review in the Prevention of Herpes Zoster and Postherpetic Neuralgia. BioDrugs. 2016;30(3):243-54. https://doi.org/10.1007/ s40259-016-0180-7

14. Cunningham AL, Heineman T. Vaccine profile of herpes zoster ( $\mathrm{HZ} /$ su) subunit vaccine. Expert Rev Vaccines. 2017;16(7):1-10. https:// doi.org/10.1080/14760584.2017.1329012

15. Privor-Dumm LA, Poland GA, Barratt J, Durrheim DN, Deloria Knoll $M$, Vasudevan P, et al. A global agenda for older adult immunization in the COVID-19 era: A roadmap for action. Vaccine. 2021; 39(37): 5240-50. https://doi.org/10.1016/j.vaccine.2020.06.082

16. Rampakakis E AC, Karellis A, Sampalis JS, Johnson K, Monsanto HA, Acosta CJ. Measuring the burden of herpes zoster disease in Costa Rica. Acta Med Costarric. 2017;59(4):146-52. https://pesquisa. bvsalud.org/portal/resource/pt/biblio-886389

17. Hales CM, Harpaz R, Ortega-Sanchez I, Bialek SR, Centers for Disease Control and Prevention. Update on recommendations for use of herpes zoster vaccine. MMWR Morb Mortal Wkly Rep. 2014;63(33):729-31. PMID: 25144544. 